\title{
XXXVIII. On the tides in the bay of Morecambe
}

\section{John Nixon Esq.}

To cite this article: John Nixon Esq. (1834) XXXVIII. On the tides in the bay of Morecambe, Philosophical Magazine Series 3, 5:28, 264-278, DOI: 10.1080/14786443408648458

To link to this article: http://dx.doi.org/10.1080/14786443408648458

册 Published online: 01 Jun 2009.

Submit your article to this journal 준

Џ Article views: 2

Q View related articles $₫$ 


\section{Mr. J. Nixon on the Tides in the Bay of Morecambe.}

expected to have their corresponding influence upon the final result.

782. It is to me a great satisfaction that the extreme variety of secondary results have presented nothing opposed to the doctrine of a constant and definite electro-chemical action, to the particular consideration of which I shall now proceed.

[To be continued.]

\section{On the Tides in the Bay of Morecambe. By John Nixon, Esq.*}

THE beautiful bay of Morecambe extends from the Irish Sea seventeen miles in a north-easterly direction. From the entrance (between Rossal Point and Walney Island) to Humphrey Point, a distance of fourteen miles, beyond which the bay contracts into two narrow arms, the width varies from eleven to fifteen miles.

At the mouth of the bay, situate some little distance below the parallel of latitude wherein the tidal current from St. George's Channel meets that from the North Channel, we have shallows to the north-west, and to the south-east deepening water up to the margin of the sands by the shore. Off Rossal Point the soundings at low water are nearly thirty fathoms, but the depth decreases gradually up the same side of the bay, and towards the opposite shore, as far as to Poulton (a distance of twelve miles north-east) where the sea ebbs out, or nearly so, at high tides. From about Poulton draw a line in a direction to bisect the entrance to the bay, and we shall have, to the right, sands either laid bare, or only one to three fathoms under the sea at low-water spring tides. The Grange and Furness channels range by opposite shores the length of these sands, the former conveying at low water to the open sea the Kent, Winster, and Keer, and the latter the waters from Windermere and Coniston lakes, \&c. After heavy rains the swoln rivers will sometimes deviate from their previous course on the sands, and cause the main channels to shift. From the great width of the bay these noble waters cannot, however, materially affect the rate or height of the tide; in fact, on a calm day they may be seen from the hills along the coast $f$, flowing apparently in their usual direction over the denser sea water, from which they are distinguishable by their superior smoothness of surface.

Off Heysham, Poulton, Hest-bank, Warton, \&c., the tides

* Communicated by the Author. †From Warton Crag in particular. 
Mr. J. Nixon on the Tides in the Bay of Morecambe. 265

assume in moderate weather the character of calm tides*, the slight waves fronting the bottom of the bay with a crest parallel to a line drawn across its entrance, or from south-west to north-east. It is, however, probable that rapid currents are formed by the tide on rounding the headlands which oppose its progress in the lower part of the bay, as I have observed the tide make the entire circuit of Silverdale Bay and Point, strongly agitated and at a tremendous rate, under an opposing wind of great force + .

The time of high water is not the same throughout the bay, the greatest differences being supposed to exist between opposite parts of the shores. Winds from the south-west quarter, blowing strongly either in the bay or up the Irish Channel, are considered to accelerate the time of high water and increase the height of the tidesł, retarding, on the other hand, the time of ebb, and sustaining the waters above their usual level. Some of the highest tides in the bay have taken place under similar circumstances at neaps. To winds from the north-east quarter effects exactly opposite are attributed, those from the south-east or north-west being termed neutral. The highest tides, about thirty feet, are held to be about Peel Castle, where there is only half a fathom of water at springtides, low water; but those at Heysham, ten miles east of that locality, it will be proved, are scarcely inferior.

\section{On the Tides at Hest Brealwwater.}

The breakwater, situate half a mile north-west of Hestbank, (a village three miles north of Lancaster,) projects about fifty yards in a north-west direction from a gravel bank thrown up as a road to it from the shore, from which it is nearly three hundred yards distant. It is constructed of solid masonry, perpendicular on every side to the height of its surface, which is about level with high-water neap tides. The force of the waves in stormy tides is broken on its south-west side by a connected sloping bank formed of fragments of rock. A lofty pole, formerly used for hoisting a lamp, is fixed perpendicularly within a stone pedestal let into the surface of the breakwater at a distance of seven yards from its north-west

* Between Kent's Bank and Silverdale the tide is said to form a bore, advancing breast high, with a roaring noise, at the full speed of a horse. (The bore of the Ganges runs at the rate of seventean miles an hour for seventy miles.)

+ On the Ist of September last, memorable for the number of shipwrecks.

$f$ The sailors are of opinion that strong dews and heavy rains increase the height of a tide (?).

Third Series. Vol. 5. No. 28. Oct.1834. $\quad 2 \mathrm{M}$ 


\section{Mr. J. Nixon on the Tides in the Bay of Morecambe.}

end. The Keer, which, flowing in its usual channel, passed close by the breakwater at the time of its erection (only a few years ago), soon after receded from it considerably to the north-west; and again altering its course after the rainy autumns of 1829 and 1830*, fell into the Grange channel four or five miles above their previous confluence off Poulton. The height of the north-east or lee side of the breakwater, originally upwards of sixteen feet, is now reduced by the gradual deposition of warp to nine feet $t$. On this account a costly structure for the convenient unshipping of goods destined to be forwarded by the Lancaster canal, is now become unserviceable and suffered to go to ruin $\neq$.

In order to find the time, \&c., of high water, the east side of the breakwater pole was divided, from its base upwards, to a sufficient height, into feet, and after a few days' observations into half-feet. A board, similarly divided, was nailed per.pendicularly to one of the piles (the nearest to the pole) on the lee side of the breakwater, its upper division being placed exactly level with the base of the pole by means of a spirit-level. From the shore (little above the level of the breakwater) these divisions, which were marked and numbered with white paint, were distinctly seen through a 20-inch telescope, and little difficulty occurred in determining in calm weather, and especially at high tides, the nearest minute by the watch when the water appeared level with any division $\$$. With a rough sea dashing over the breakwater it required most vigilant observation to decide when the waves fluctuated as much above as below the mark, or subsided for some moments to the level of it. The observations at neaps, generally more uncertain, were facilitated by the comparative tranquillity of the water by the divided board. The divisions on the pole and board served also to mark the extreme height of the tide above or below the surface of the breakwater.

When the perpendicular rise and fall of a tide are uniform in rate, half the sum of the times at which it has risen and

- At the same period a low sand-bank, called Priest Skear, lying a mile north of the breakwater, gradually assumed the form of an island. Not many years ago it was pasture land connected with the shore, now half a mile distant.

+ This has been explained in Treatises on Harbours. Beneath the warp lies the red marl with ironstone, ranging between Carnforth and Bare. It appears to be the same rock which runs in patches between Ingleton and Kirkby Lonsdale.

I About thirty years ago the Ulverston canal was rendered nearly useless by a similar shifting of a branch of the Furness channel.

$\S$ In general it was most difficult to mark with certainty the time when the sea became level with the base of the pole. 
Mr. J. Nixon on the Tides in the Bay of Morecambe. 267

afterwards descended to the same (height or) division, will give, alike from observations of every division, the time of high water; but as the rate will generally vary, not only from astronomical causes, but also from sudden changes in the force or direction of the wind, it follows that the series of times obtained from the several divisions will neither coincide with each other, nor with the true instant, the error increasing (irregularly) from the highest to the lowest division noted. In the course of observations, frequently protracted to three hours, as the extreme difference between the times obtained never exceeded five minutes, the one derived from the highest division rarely required a correction of moment to reduce it to the true instant of high water.

The watch made use of, which has a detached lever, but is without compensation-curb, \&c., keeps a tolerably uniform rate when not exposed, as was sometimes the case, to violent shocks on travelling. Its error was ascertained from time to time at a station near Hest-bank from sets of observations made in the afternoon, of the instants the sun's upper and lower limbs had descended to a certain altitude (measured by a box sextant,) above the sea at the horizon, or later in the afternoon above its margin (?) about Peel Castle, a distance of $15+$ miles. The dip of the sea, found by the sector to vary, according to the state of the tide and refraction, from $8^{\prime} 0^{\prime \prime}$ to $11^{\prime} 28^{\prime \prime}$, was taken at $10^{\prime} 0^{\prime \prime}$. On one occasion the sun's height was obtained in the morning by reflection from the tranquil surface of the canal. (See Table I.) From the highest part of the north-east battlement of the canal bridge on the Oversands road from Hest-bank, go two and a half feet towards the opposite side of the bridge, and the station, 51 feet distant, (the east end of the roadside wall, ) will be in a line with the breakwater pole. The height of the wall top above the long level of the Lancaster canal (extending from Preston nearly to Burton-in-Kendal, ) measured 13 feet. The (trigonometrical) latitude was found to be $54^{\circ} 5^{\prime} 34^{\prime \prime}$ not and the longitude $2^{\circ} 48^{\prime} 5^{\prime \prime}$ (or $11 \mathrm{~min} .12 \mathrm{sec}$. in time) west of Greenwich. The distance from Hest-bank wall to the Breakwater pole, 2339.3 feet $t$, was calculated from the angles taken by the four-inch theodolite at both ends of a base line extending 855 feet (as measured by a corrected tape) along the west margin of the Oversands road near the bathing-

* In 1829, the fall to the canal was 17 feet 3 inches, and 17 feet in 1832, the fall to the wall top being 4 feet 1 inch.

$\uparrow$ Differing little from, but preferable to, the length obtained by a triangulation connected with that of Colonel Mudge.

$2 \mathrm{M} 2$ 
268 Mr. J. Nixon on the Tides in the Bay of Morecambe.

house. With this distance, and the vertical angles measured at the wall by the sector, we get

Height of wall above breakwater pole top, (the) Feet. mean of three observations in 1829 and 1832,$\} 43.2$ varying from 43.1 to 43.2$)$....................

Height of wall above pole base, (the mean of eight observations, in 1829,1830 , and 1832,$\} 71 \cdot 2$ varying from 70.9 to $71 \cdot 4) \ldots \ldots \ldots \ldots \ldots \ldots \ldots . . . . .6$

Hence the canal will be 30.2 feet above the top, and 58.2 above the base of the pole.

Notwithstanding the present dilapidated state of the breakwater, the measurements do not indicate any alteration of level in the pedestal of the pole.

\section{Height of Neap and Spring Tides at Heysham.}

The tide deserts Hest sands soon after half-ebb, and at Poulton, two miles to the west-south-west, it either ebbs out at spring tides, or is cut off by a two-foot bar of sand. In Heysham lake, 5 miles south-west of Hest-bank, there is, however, constantly deep water, communicating without current (?) with the open sea.

July 20, 1832, two days before the neap tides were at a minimum, a stake was driven just within the margin of the lake down to the exact level of its unruffled surface when at the lowest (or about $10^{\text {h }} 2^{\text {m }}$ A.M., mean time). The height of high water was marked (in a dead calm) true to an inch or two (at $3^{\mathrm{h}} 57^{\mathrm{m}}$ P.M.) by a similar stake driven ( 820 yards to the eastward of the other) into the sands near the road from Upper Heysham to the shore. The difference of level of the two marks was found by the six-inch theodolite and two sixfeet levelling staves, divided on both sides into inches, of which the fractional parts, as the staves were unfurnished with sliding vanes carrying verniers, were visually estimated. The level (bubble) of the theodolite was properly adjusted, but from a defect in the screw-key, the line of collimation, which pointed too high by one tenth of an inch in a distance of fifty feet, could not be rectified. To meet the evil, the instrument was invariably placed (between and) equidistant from the two staves previously set up perpendicularly (by a plumb-line) at distances from each other not exceeding 100 feet*. Two staves were indispensable on account of the slight, yet gradual

* Or, when the sum of the distances from the instrument to the staff in one direction equal the sum of those to the staff in the other direction, a compensation of errors takes place. 
sinking of the heavy instrument within the sand, which required that both levels should be taken as nearly at the same time as possible*. The total fall appeared to be 18 feet 6 inches, but a solitary limestone, considered as the standard height for extreme neaps, was situated 1 foot 9 inches below the level of our mark, which would reduce the total height of the tide by double (?) that quantity, or to 15 feet.

July 28, 1832, the day previous to the highest spring tide (the weather being perfectly calm), the fall from the level of high water (at $11^{\mathrm{h}} 32^{\mathrm{m}}$ A.M.) to our stake near the shore measured 6 feet 5 inches, but that from the stake by the lake down to the level of the latter at low water (at $5^{\mathrm{h}} 57^{\mathrm{m}}$ P.M.) did not exceed 4 feet 7 inches, although a continuous fall was perceptible nearly up to the time quoted $\uparrow$. The total height of the tide will therefore be 29 feet 3 inches. On this occasion, as the theodolite was completely adjusted, the difference of level between the two stakes driven down at neaps was carefully remeasured, and made to be 18 feet 3 inches, or only 3 inches less than previously.

In strictness the rise as well as the fall of a tide should be obtained, and the mean taken for its correct height.

Measurement by the Dip of the Height of the Tides.

No ray of light originating at any point $(\mathrm{P})$ on the (spherical) surface of the sea (PL) could pass below the level of the horizontal plane $\mathrm{PD}$ (which is perpendicular to the vertical $P C$ ) without being absorbed in the sea. At the point of intersection (D) of this plane with any other vertical, as DC, the angle HDP, or depression of $\mathrm{P}$ below the horizontal plane or line $\mathrm{DH}$, is termed the true dip, and is equal to the arc contained between

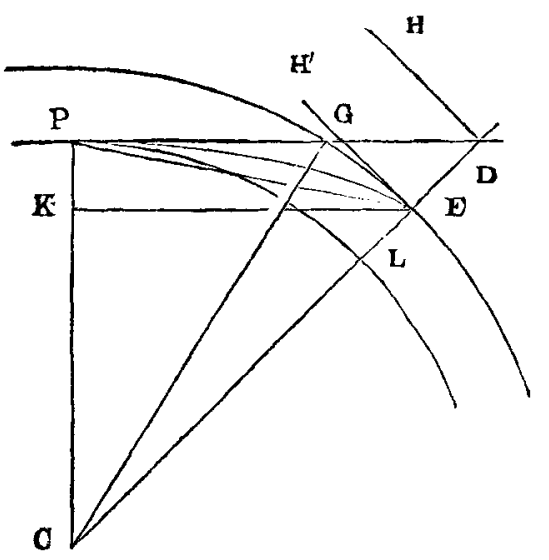
the two verticals PC and DC, or the angle PCD.

* As an additional precaution one staff was read off before as well as after noting the other, and the mean of both readings registered.

+ The fisliermen hold that there is a difference of half an hour between the duration of ebb and flow in Heysham lake. 


\section{Mr. J. Nixon on the Tides in the Bay of Morecambe.}

The ray from $P$, initially in the direction of $D$, being constantly curved downwards in its passage from the effects of atmospherical refraction, will cut the vertical $\mathrm{DC}$ at a point $\mathrm{E}$ lower than $\mathrm{D}$ by (nearly) the tangent of an angle DPE, which bears a constant proportion to the true dip (or contained arc). At $E$ the depression of $P$ is evidently less than at $\mathrm{D}$ by the angle $\mathrm{PEK}=\mathrm{DPE}$, or the angle of refraction; but as $P$ will not be seen from $E$ in the direction $E P$, but in a tangent to the extremity of the curved ray at $P$, it will appear elevated above $P$ by the angle of refraction: hence the apparent dip at $\mathbf{E}$ will be less than the true dip at $\mathbf{D}$ by twice the angle of refraction*.

DL being the height of $\mathrm{D}$ above the level of the sea, that of $\mathrm{E}$ will be equal to $\mathrm{DL}$ minus DE (or the part cut off by refraction). As the angle DPL is constantly half the dip at $D$, (or half the contained arc PCD, ) it follows that the angle DPE will bear twice the proportion to that of DPL that the refraction does to the contained arc. When the height in feet of $\mathrm{E}$ is given, that of $\mathrm{D}$ may be found by increasing $\mathrm{E}$ by $\frac{2 \mathrm{E}}{n-2}, n$ being the ratio of the contained arc to the refraction. Thus, if $\mathrm{E}$ be 80 feet, and the refraction $\frac{1}{10}$ th of the arc, then will the height of $\mathrm{D}$ be $80+\frac{80 \times 2}{10-2}=100$ feet. The true dip for $\mathrm{D}$ being $10^{\prime} 37^{\prime \prime}$, that for $\mathrm{E}$ will be $\left(10^{\prime} 37^{\prime \prime}\right.$ minus $\frac{1}{10}$ th, or $) 9^{\prime} 33^{\prime \prime}$, and its apparent $\operatorname{dip}\left(10^{\prime} 37^{\prime \prime}\right.$ minus $\frac{1}{5}$ th, or $)$ $8^{\prime} 30^{\prime \prime}$. (The true dip for $\mathrm{G}$ ( $=80$ feet) would be $9^{\prime} 30^{\prime \prime}$, or $3^{\prime \prime}$ less than for $\mathrm{E}_{\text {.) }}$

Although well aware that the difference between the true and apparent dip was subject to great and unaccountable fluctuations, yet I flattered myself that by measuring along with the depression of the horizon of the sea that of a fixed object on the shore beyond, situate nearly in the same direction and at about an equal distance, I should then be able to ascertain the deviation of the refraction at low water from its amount at high water, the latter being equal to the difference between the apparent dip and that calculated from the measured height of the eye above the sea at the breakwatert. The plan, which, with one exception, appears to have been

* $G$, the point of intersection of the unrefracted ray $P D$ with a vertical at a height equal to that of $\mathrm{E}$, has a less extensive horizon than the latter by (twice) the arc GE. $D$ is elevated above $E$, yet their horizons, as that of the former is not affected by refraction, are equal.

+ Any probable difference in the times of high water at the horizon of the sea and at the breakwater would scarcely exceed the duration 
tolerably successful, would probably have been completely so had the base of Walney lighthouse (the object selected for reference) been observed in lieu of its ill-defined conical top. At Hest-bank wall, where the measurements were made by the sector, the height, though scarcely more than requisite to obtain at low water an unobstructed view of the open sea, throws its horizon to a distance of 9 to 11 miles, and thus renders it necessary to have the dip true to $3^{\prime \prime}$ or $4^{\prime \prime}$ in order to insure to the calculated height of the eye the accurncy of one foot. The bank is steep, and extends to the south-west and north-east. At high water the station may be 200 yards distant from the sea in the direction observed, (a little left of the lighthouse, which lies to the west by south,) but at low water sands, intersected by channels and pools of water, intervene for several miles.

Generally each day's observations are arranged below, in an order to exhibit, - 1st, The variation at low water of the depression of the lighthouse from its amount at high water; 2nd, the refraction at high water, or difference between the observed dip and that calculated from the measured height of the eye; 3rd, the height of the eye at low water, computed from the observed dip corrected by a refraction differing from that obtained at high water by the corresponding variation in the depression of the lighthouse; 4th, the dip answering to the height of the eye at low water, derived from a table, founded on the measurements at Heysham; 5 th, the consequent error of the estimated refraction and height of the eye.

September 14th, 1829.

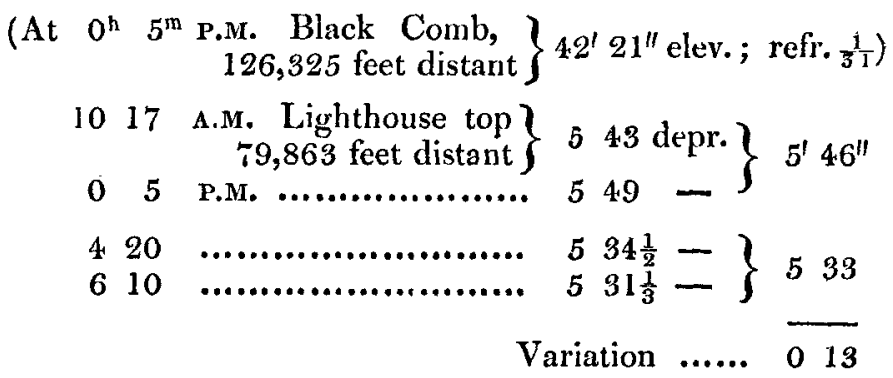

of the hang of the tide. Granting even a difference of level in the sea at high water at the two localities, we should then form a false estimate of the refraction, yet as the calculated dip at low water would be nearly equally in defect or excess with that at high water, their difference, or height of the tide, would not be materially affected. 
272 Mr. J. Nixon on the Tides in the Bay of Morecambe.

At $10^{\text {h }} 2^{\text {m }}$ A.M. Dip 8' 53"; Eye 70.2 feet; refr. $+0^{\prime} 1^{\prime \prime}$

$$
\begin{aligned}
& 1035-830-67.5-013 \\
& 110-824 \frac{1}{2}-65.4-011 \\
& 1130-820 \frac{1}{2}-64.2-010 \\
& 1146-824 \frac{1}{2}-64 \cdot 4-04 \cdot 6 \frac{1}{2} \\
& 1158-822-64.7-010 \\
& 030 \text { P.M. }-830-66.7-010 \\
& \text { Mean ...... } 829 \quad+0 \quad 8 \frac{1}{2} \\
& \begin{array}{lllllllll}
\text { Half variation } & \ldots & \ldots & \ldots & \ldots & \ldots & \ldots & +0 & 6 \frac{1}{2}
\end{array} \\
& \text { Mean refraction ( }\left(\frac{0^{\prime} 15^{\prime \prime}}{83 \frac{3}{2}} \text { or) } \frac{1}{34} \text { th. } \quad \ldots \quad \ldots \quad+0 \quad 15\right.
\end{aligned}
$$

At $5^{\text {h }} 12^{\text {m }}$ P.M. Dip $9^{\prime} 58^{\prime \prime}$.

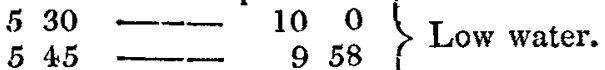

$$
\begin{aligned}
& 60-955
\end{aligned}
$$

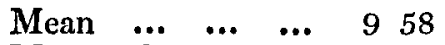

Mean refraction $\frac{3}{3} \frac{1}{4}+018 \frac{1}{2}$

Half variation $\quad \cdots+0 \quad 6 \frac{1}{2}$

Corrected dip and height of eye $10^{\prime} 23^{\prime \prime}=956$ feet.

Tabulated do. ... ... $1027=97^{\circ} 0$

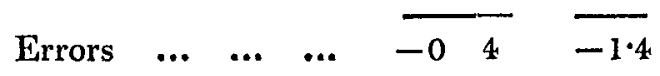

September 15 th 1829 . $\begin{array}{cccc}\text { At } 10^{\mathrm{h}} 50^{\mathrm{m}} & \text { A.M. Lighthouse top } 5^{\prime} 49^{\prime \prime} \text { depr. } \\ 0 & 55 & \text { P.M. } & 5 \\ 6 & 51 & 50^{\prime \prime}\end{array}$
A.M.
$435-$
60
A.M. Black Comb 4.248 elev.; refr. $\frac{1}{19}$.)
$\begin{array}{ll}6 & 5\end{array}$
P.M. Lighthouse top $540 \frac{1}{2} \mathrm{depr}$.

Morning variation $-1^{\prime} 15^{\prime \prime}$; evening variation $-9 \frac{1}{2}^{\prime \prime}$.

At $10^{\mathrm{h}} 43^{\mathrm{m}}$ A.m. Dip $8^{\prime} 45 \frac{1}{2}^{\prime \prime}$; Eye $71 \cdot 3$ fet ; refr. $+0^{\prime} 12^{\prime \prime}$.

$$
\begin{aligned}
& 115 \text { - } 849 \text { - } 88.7-01 \\
& 1147-830 \frac{1}{2}-64.9-03 \\
& 020 \text { P.M. } 829-64.0-8400 \frac{\mathrm{I}}{2} \\
& 048-823-64.5-\ldots+08 \frac{1}{2} \\
& \text { Mean ...... } \overline{835 \frac{1}{2}}
\end{aligned}
$$

Mean morning refraction $\left(4 \frac{\mathrm{I}}{2}+37 \frac{1}{2}\right)=\frac{0^{\prime} 42^{\prime \prime}}{844^{\prime}}=\frac{1}{12} \cdot 5^{\circ}$

Do. evening do. $\left(4 \frac{1}{2}+5\right)=\frac{09 \frac{1}{2}}{840}=\frac{1}{5} 5$. 
Mr. J. Nixon on the Tides in the Bay of Morecambe. 273

\begin{tabular}{|c|c|c|c|}
\hline $\begin{array}{l}5^{\mathrm{h}} 45^{\mathrm{m}} \\
615\end{array}$ & A.M.; Dip & $\ldots$ & $\left.\begin{array}{ll}8^{\prime} & 43^{\prime \prime} \\
8 & 41\end{array}\right\}$ \\
\hline $\begin{array}{l}\text { Mean .. } \\
\text { Refraction } \\
\text { Half mornin }\end{array}$ & 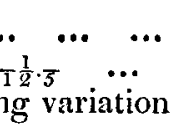 & & $\begin{aligned} 842 \\
+\quad 48 \\
+\quad 37 \frac{1}{2}\end{aligned}$ \\
\hline
\end{tabular}

Corrected dip and height of eye $10 \quad 7 \frac{1}{2}=91 \cdot 0$ feet.

Tabulated do. $1030 \frac{1}{2}=98 \cdot 0$

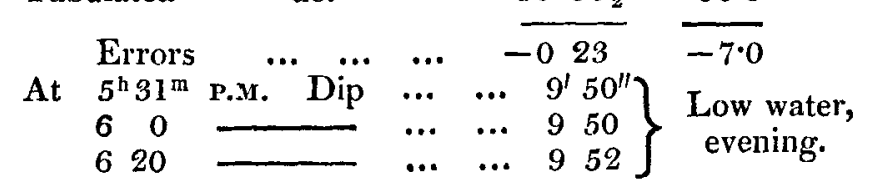

$\begin{array}{cccccc}\text { Mean } & \ldots & \ldots & \ldots & \ldots & 951 \\ \text { Refraction } \frac{1}{5 \frac{1}{5}} & \ldots & \ldots & \ldots & \ldots & +11 \frac{1}{2}\end{array}$

Half evening variation $\ldots \quad \ldots+5$

Corrected dip and height of eye $10 \quad 7 \frac{1}{2}=91 \cdot 0$ feet.

Tabulated
Errors $\quad$ do. $\quad \ldots \quad-\frac{1030 \frac{1}{2}}{023}=\frac{98 \cdot 0}{-7 \cdot 0}$

In the morning there was a strong white frost, which did not recur in the evening. To account for our estimate of the refraction being so much in defect, we must either suppose our tabulated height of the (equinoctial) tide (34 feet) in excess, or that the variation of refraction was less for the lighthouse than the horizon of the sea, and to precisely the same amount in the morning as evening! At noon, which was bright and warm, the refraction for the dip and the lighthouse were both less by $4 \frac{1}{2}$ than on the preceding day.

September 16th, 1829.

(At $2^{\mathrm{h}} 35^{\mathrm{m}}$ P.M. Black Comb, $42^{\mathrm{l}} 3 \frac{1}{2}^{\prime \prime}$ elev. ; refr. $\left(\frac{1}{24}\right)$ $\left(\begin{array}{llll}6 & 55 & \text { A.M. do. } & 4255 \frac{1}{2} \\ 0 & 35 & -\frac{1}{17}\end{array}\right.$

035 P.M. Lighthouse top $533 \frac{5}{2}$ depr.

645 A.M. do. $512 \quad$

(10 25 A.M. do. $517 \quad-$ )

Variation $-21 \frac{1}{2}$

At $0^{\text {h }} 23^{\text {m }}$ 1.M. dip $8^{\prime} 17^{\prime \prime}$; Eye 66.3 feet; refr. $+21^{\prime \prime}$

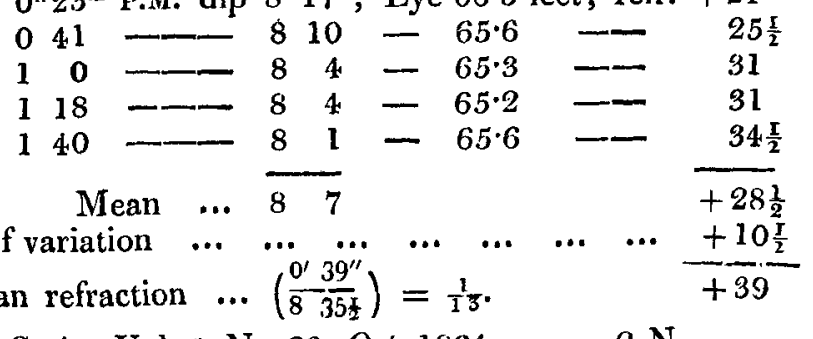

Third Series. Vol. 5. No. 28. Oct. 1834. $2 \mathrm{~N}$ 
274 Mr. J. Nixon on the Tides in the Bay of Morecambe.

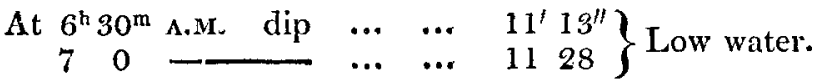

$$
\begin{aligned}
& \begin{array}{llllll}
\text { Mean } \quad \ldots & \ldots & \ldots & 11 & 20 \frac{1}{2}
\end{array} \\
& \text { Refraction } \frac{1}{13} \quad \ldots \quad \ldots \quad \ldots \quad \ldots \quad+57 \\
& \begin{array}{lllll}
\text { Half variation } & \ldots & \ldots & \ldots & +10 \frac{1}{2}
\end{array} \\
& \text { Error's } \quad \ldots \quad \ldots \quad+2 \quad 3 \quad+41 \cdot 7 \quad
\end{aligned}
$$

The refraction for the dip at noon is unusually great, but that for Black Comb and the lighthouse, is nearly equally in excess. The morning was frosty, and the horizon of the sea, although dull at the first observation for low water, became quite clear at the second. The refraction appears, however, to have been $55 \frac{\mathrm{I}}{2}{ }^{\prime \prime}$ negative; a probable consequence of a frosty morning succeeding a warm evening, in which case the air would be considerably cooler than the sea. Under similar circumstances, Biot has observed the dip at sea to be 4 or 5 minutes greater than úsual.

August 24th 1829.

At $2^{\text {h }} 0^{\mathrm{m}}$ P.M. (Low water) dip $\quad 10^{\prime} 0 \frac{\mathrm{I}}{2}{ }^{\prime \prime}$

$$
230-152 \frac{\mathrm{r}}{2}
$$

$\begin{array}{lllllllll}\text { Mean } & \ldots & \ldots & \ldots & \ldots & \ldots & 9 & 56 \frac{1}{2}\end{array}$

Mean noon refr. Sept. $14,15,16=\frac{1}{38}+15 \frac{1}{2}$

Corrected dip and height of eye $\quad 1012=92 \cdot 3$ feet. $\begin{array}{llll}\text { Tabulated do. } & \text {... } & 10 & 4 \frac{1}{2}=90.0\end{array}$

$$
\text { Errors } \ldots \ldots+\ldots \quad \ldots+\ldots+0 \quad 7 \frac{1}{2}+2 \cdot 3-
$$

Height of eye at high water $92 \cdot 6$ feet. Lighthouse unobserved.

$$
\text { August 25th, } 1829 .
$$

At $\mathcal{Q}^{\mathrm{h}} 30^{\mathrm{m}}$ P.M. Low water, dip

245

315

Mean

Mean noon refraction $\begin{array}{lllll} & \cdots & \cdots & \cdots\end{array}$

Corrected dip and height of eye

Tabulated

Errors $9^{\prime} 38^{\prime \prime}$

938

$9 \begin{array}{lll}9 & 41\end{array}$

939

$+15$

$$
\begin{aligned}
954 & =87.0 \mathrm{ft} . \\
10 \quad 5 \frac{1}{2} & =90.3
\end{aligned}
$$


Mr. J. Nixon on the Tides in the Bay of Morecambe. 275

Height of eye at high water, 72 feet. Lighthouse unobserved.

October 13th, 1830.

At $9^{\mathrm{h}} 22^{\mathrm{m}}$ A.M. Lighthouse top, depr. $5^{\prime} 40 \frac{1^{\prime \prime}}{2}$.

$\{$ High water.

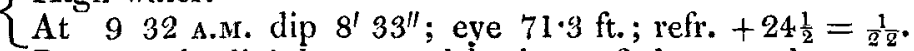

Between the lighthouse and horizon of the sea, there appeared a bank of white vapour.

High Water. October 14th, 1830.

At $9^{\text {h }} 42^{\text {m }}$ A.M. dip $8^{\prime} 41 \frac{1}{2}$; ; eye $70 \cdot 7 \mathrm{ft}$; refr. $+15 \frac{1}{2}{ }^{\prime \prime}$

$$
\begin{aligned}
& 1012-839 \frac{1}{2} \quad 70.1-13 \frac{1}{2} \\
& 1042-840 \frac{1}{2} \quad 70.7-15 \frac{1}{2} \\
& \text { Mean } \ldots \quad \overline{840 \frac{1}{2}} \quad \overline{15}={ }^{5} \frac{1}{6} \text {. }
\end{aligned}
$$

At 435 P.M. Low water; dip $9^{\prime} 35^{\prime \prime}$

Refraction at noon $\frac{1}{36} \quad \ldots \quad+16 \frac{1}{2}$

Corrected dip and height of eye $951 \frac{1}{2}=86.2 \mathrm{ft}$.

Tabulated do. $1011=92 \cdot 0$

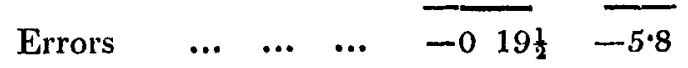

The refraction $\left(+36^{\prime \prime}\right)$ must have been more than double its value at the time of high water.

High water.

October 15th, 1830.

At $9^{\mathrm{h}} 58^{\mathrm{m}}$ A.M. dip $8^{\prime} 45 \frac{1}{2}{ }^{\prime \prime}$; eye 70.7 ft.; refr. $+10 \frac{1}{2}$

$$
\begin{aligned}
& 1019-837 \frac{1}{2}-69 \cdot 7-14 \frac{1}{2} \\
& 1048-840-68.3-6 \frac{1}{2} \\
& 1116-839 \frac{1}{2}-69.7-12 \frac{1}{2}
\end{aligned}
$$

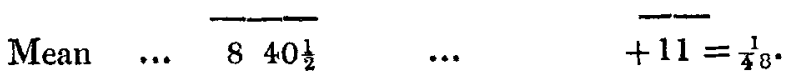

October 16th, 1830.

High-roter.

At $11^{\mathrm{h}} 8^{\mathrm{m}}$ A.m. $\operatorname{dip} 8^{\prime} 41^{\prime \prime}$; eye $68.5 \mathrm{ft}$; refr. +5

1131 - 835 - 68.4 - 12

Mean $\quad . . \quad-838 \quad+8 \frac{1}{2}$ or $\frac{1}{62}$. 
TABLE I. Observations for determining the Error of the Watch.

\begin{tabular}{|c|c|c|c|c|c|}
\hline 1832. & $\begin{array}{l}\text { Alti- } \\
\text { tude. }\end{array}$ & Sun's L,L. & Sun's U. L. & $\begin{array}{c}\text { Error, } \\
\text { mean time. }\end{array}$ & Daily Rate. \\
\hline $\begin{array}{c}\text { July } 7 . \text { P.Mr. } \\
10 . \\
12 . \\
14 . \\
18 . \\
23 . \\
26 . \\
\\
\text { † A ug. 1. A.M. } \\
7 . \text { P.M. }\end{array}$ & $\begin{array}{rr}29^{\circ} & 30^{\prime} \\
28 & 30 \\
32 & 5 \\
31 & 0 \\
30 & 0 \\
32 & 0 \\
30 & 30 \\
29 & 0 \\
24 & 0 \\
23 & 0 \\
32 & 30 \\
31 & 30 \\
30 & 30 \\
22 & 30 \\
21 & 30 \\
20 & 30 \\
19 & 45 \\
21 & 0\end{array}$ & $\mid \begin{array}{rrr}4^{\mathrm{h}} & 49^{\mathrm{m}} & 25^{\mathrm{s}} \\
4 & 56 & 5 \\
4 & 32 & 0 \\
4 & 39 & 0 \\
4 & 46 & 35 \\
4 & 31 & 40 \\
4 & 42 & 14 \\
4 & 52 & 40 \\
5 & 27 & 10 \\
5 & 34 & 30 \\
4 & 28 & 25 \\
4 & 35 & 5 \\
5 & 42 & 10 \\
5 & 35 & 10 \\
5 & 42 & 0 \\
5 & 48 & 50 \\
7 & 2 & 25 \\
5 & 34 & 45\end{array}$ & 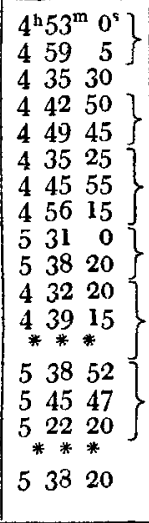 & $\begin{array}{l}+3^{\mathrm{mm}} 30^{\circ} \\
+522 \\
+630 \\
+720 \\
+1123 \\
+1526 \\
+175 \\
+1856 \\
+2328\end{array}$ & 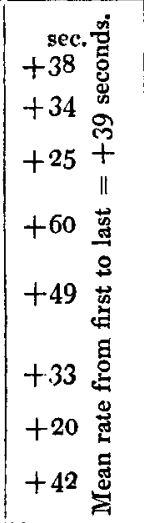 \\
\hline
\end{tabular}

\section{Table II. Register of the Tides at Hest-Bank.}

Explanation of the Columns.-1st, The day of the month. 2nd, The number of divisions (on the breakwater pole) observed: the asterisk denotes that the corresponding times for high water increased or decreased seriatim. 3rd, The height of the top of the pole above the level of the tide at high water. 4th, 'The instant of high water calculated immediately from the times, by the watch, at which the tide reached (during the flow and ebb) the level of the several divisions observed. 5 th, Tlie last column corrected for the error of the watch, mean time, Hest-bank. 6th, The predicted time (by Holden's Tables) of high water at Liverpool, reduced to mean time and the meridian of Hest-bank $\downarrow$. $7 \mathrm{th}$, The direction and force of the wind. 8 th, The state of the surface of the sea.

+ By Reflection, (see page 267 for Dip, \&c.)

$\neq$ The latitude of Liverpool is $53^{\circ} \mathrm{Z4}^{\prime} 40^{\prime \prime}$ north, and its Iongitude 20.58' 55" west. 
Mr. J. Nixon on the Tides in the Bay of Morecambe. 277

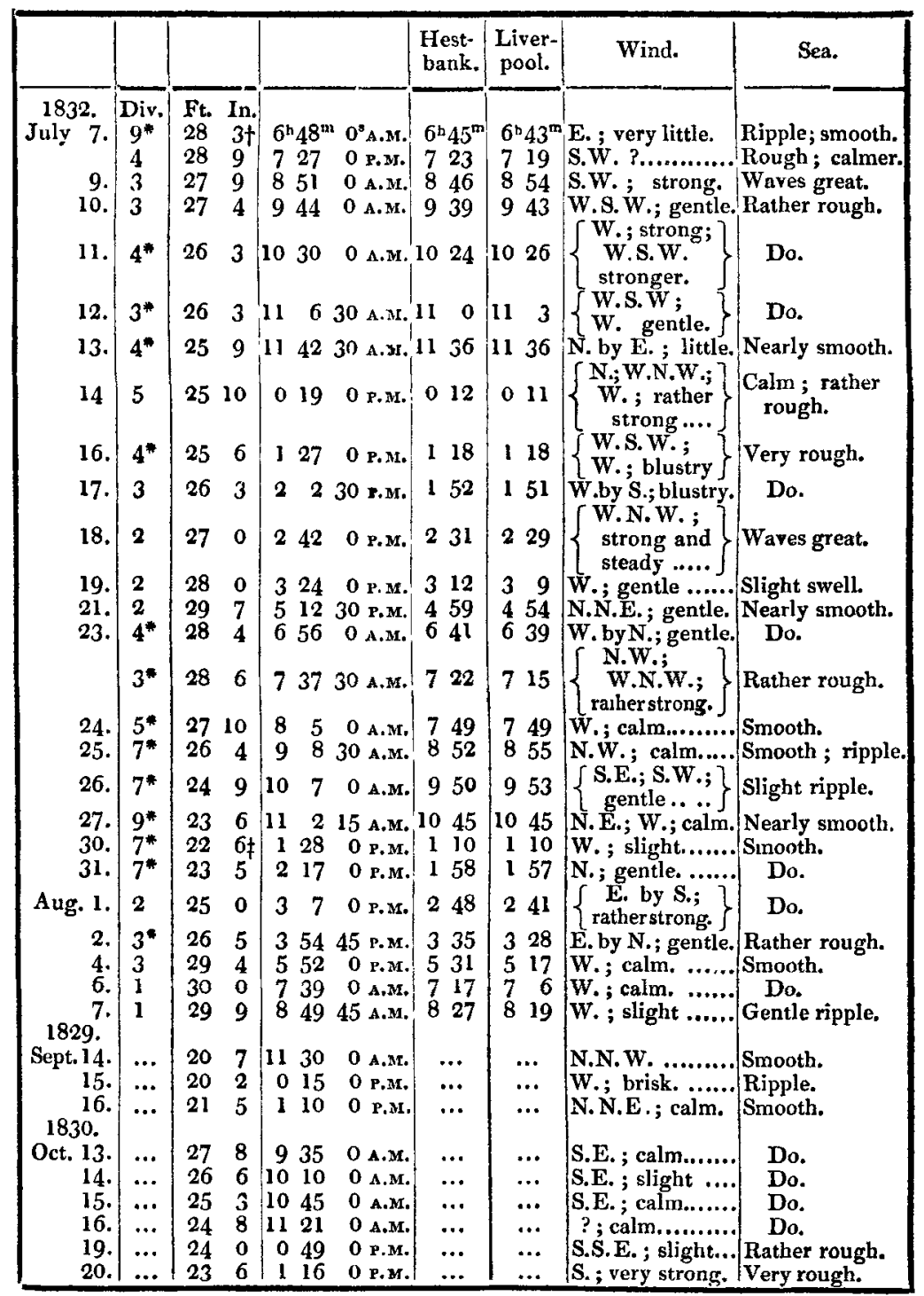

$\uparrow$ These numbers plus 30.2 feet will give the height of the Lancaster canal above the tides at bigh water.

$¥$ The preceding tide would be about 21 feet 6 inclies below the top of the pole. 
$278 \mathrm{Mr}$. J. Barton on the Influence of high and low Prices

N. B. The moon's phases were,

Nero. June 28 th, at $6^{\mathrm{h}} 50^{\mathrm{m}}$ A.M.

Full. July 12 th, $\quad 1049$ P.M.

Nere. July 27 th, $\quad 150$ P.M. $\}$ Hest-bank, mean time.

Full. Aug. 11th, 221 P.M.

Chapel Allerton, near Leeds, July $24,1834$.

JoHN Nixon.

XXXIX. On the Influence of high and loro Prices on the Rate of Mortality. By John Banton, Esq.*

IN a pamphlet which I published rather more than twelve months ago + , I stated at considerable length the results of an investigation into the influence of high and low prices on the condition of the people, as evidenced by the rate of mortality in the kingdom at large, as well as in our agricultural and manufacturing districts separately. These results were deduced from a comparison of the number of burials in the population returns with the price of wheat in each year, from 1780 , the commencement of these returns, down to 1820 , the returns of the succeeding years not being at that time printed. The subsequent completion of the work enables me now to state the results of fifty years' experience in this matter. At the same time I shall be glad to take the opportunity of saying a few words on an objection which has been urged against my conclusions by a writer in the Edinburgh Review.

The general result of my inquiry respecting the influence of the price of corn on the rate of mortality in the kingdom at large will be seen in the following statement:

\begin{tabular}{|c|c|}
\hline $\begin{array}{c}\text { Price of Wheat per Win- } \\
\text { chester Quarter reduced } \\
\text { to Bullion Value. }\end{array}$ & $\begin{array}{c}\text { Average Burials yearly } \\
\text { on each Million of } \\
\text { Population. }\end{array}$ \\
\hline Under $50 s$. & $22 \cdot 455$ \\
$50 s$. to 60 & $20 \cdot 1.5$ \\
60 to 70 & $19 \cdot 778$ \\
70 to 80 & 19.291 \\
80 to 90 & 18.257 \\
90 to 100 & $18 \cdot 117$ \\
above 100 & 22.350 \\
\hline
\end{tabular}

* Communicated by the Author.

+ Entitled, " $A$ In Indiry into the Expediency of the existing Restrictions on the Importation of Forcionn Corn." 